PF 2019 (LXXIII): 545-569

\author{
RENATA GRZEGORCZYKOWA, AGNIESZKA MIKOŁAJCZUK \\ Wydział Polonistyki \\ Uniwersytet Warszawski \\ ul. Krakowskie Przedmieście 26/28 \\ 00-927 Warszawa \\ tel. (+22) $5521021,(+22) 5520374$ \\ e-mail: amikolajczuk@tlen.pl
}

\title{
ROZUMIENIE WSPÓŁCZESNE I DZIEJE WYRAŻENIA MIŁOŚĆ WŁASNA W POLSZCZYŹNIE
}

SŁOWA KLUCZOWE: semantyka, nazwy stanów psychicznych, samoświadomość, poczucie wartości, metafora pojęciowa

KEYWORDS: semantics, mental states names, self-awareness, self-esteem, conceptual metaphor

\author{
MODERN UNDERSTANDING AND THE HISTORY \\ OF THE POLISH EXPRESSION \\ MIŁOŚĆ WŁASNA ('SELF-LOVE’)
}

\begin{abstract}
The paper presents the history of the expression miłość własna ('self-love') (which became established in Polish between the 17th and the end of the 18th century) and shows the modern understanding of the expression, including in psychology. Two ways of interpreting miłość własna ('self-love') have been distinguished as a result of semantic analysis (using linguistic databases gathering examples from the $17^{\text {th }}-18^{\text {th }}$ and $20^{\text {th }}-21^{\text {st }}$ centuries): (1) 'self-love' ${ }_{1}$ - a neutral mental state which includes: 'sense of self as a separate being, self-acceptance, desire for individual well-being, and a sense of selfworth'; and (2) 'self-love ' - negatively evaluated mental state which includes: 'exaggerated sense of self-worth, selfish desire for one's own well-being, and desire for recognition by others. Finally, the paper sets out a reconstruction of self-love metaphorical imaging, as recorded in modern Polish.
\end{abstract}




\section{Wprowadzenie}

Warto na wstępie, antycypując dalsze rozważania, spróbować odpowiedzieć na pytanie, do jakiego typu zjawisk psychicznych należy fenomen zwany miłościa własna (miłościa siebie, ros. samolubie, czes. samolaska, łac. amor sui, fr. amour propre, ang. self-love, niem. Eigenliebe, Selbstliebe). Czy jest to uczucie, jakie żywimy wobec samych siebie, co zdaje się sugerować nazwa, czy też raczej bardzo podstawowy stan świadomości, który ze względu na swoją wewnętrzność wymaga autorefleksji i nie jest łatwo werbalizowany, w odróżnieniu od innych wyraźniej odczuwanych stanów i przeżyć, zwłaszcza emocji? Psychologowie mówią o wielu przeżywanych przez człowieka stanach wewnętrznych, które nie podlegają upojęciowieniu (por. Chlewiński 1999) i nie znajdują odbicia w języku. Zauważają to także językoznawcy (por. Apresjan 2011).

Stan, który nas interesuje, można opisać jako 'poczucie (odczuwanie) odrębności własnego 'ja’, przeżycie naturalnego (podstawowego) egoizmu’. Na stan ten składają się, jak się zdaje, następujące elementy: poczucie własnej odrębności od innych (poczucie tożsamości), akceptacja siebie, pragnienie dobra dla siebie: pragnienie bezpieczeństwa, zaspokojenia potrzeb (a więc elementarny instynkt samozachowawczy) i wreszcie poczucie własnej wartości: dobrze, że jestem, jestem cenny.

Początek tego stanu poznawczo-wolitywno-aksjologicznego badacze psychologii rozwojowej wiążą z okresem rozwoju dziecka między 12 a 24 miesiącem życia, kiedy dziecko uzyskuje świadomość, że jest odrębną jednostką. Przejawia się to m.in. w tym, że widząc siebie w lustrze, rozpoznaje ono, że jest tą samą osobą, potrafi też wyrazić swoje pragnienia (zob. np. Appelt 2005, s. 102-104). Uświadomiony element aksjologiczny pojawia się u dziecka zapewne nieco później, pod wpływem wychowawczym chwalenia i ganienia, nagradzania i karania (zob. np. Smykowski 2005, s. 178-180, 192-198). Ten podstawowy stan wewnętrzny, charakteryzujący w naturalny sposób każdego człowieka, jest przywoływany w biblijnym przykazaniu: „Kochaj bliźniego swego, jak siebie samego”, to znaczy: 'chciej dla niego dobra, szanuj go, uznawaj jego wartość, traktuj go tak, jak traktujesz samego siebie', a może nawet jeszcze więcej: 'wyczuwaj jego przeżycia, jak swoje, wiedz, że on podobnie do ciebie doświadcza cierpienia, bólu, radości i innych stanów psychicznych'.

Powstaje pytanie, czy ten elementarny stan psychiczny można nazwać miłościa własną; w tym rozumieniu przysługiwałby on każdemu człowiekowi jako jego uniwersalna właściwość. Do tego problemu odniesiemy się w kolejnych częściach artykułu (zwłaszcza w p. 2, 3 i 5), na wstępie tylko sygnalizując hipotetyczną możliwość takiego neutralnego rozumienia miłości własnej i mając świadomość, 
że wydaje się ono nieintuicyjne wobec częstego użycia owego wyrażenia w kontekstach negatywnych, wskazujących na nadmierne poczucie wartości podmiotu i kierowanie się przezeń osobistymi korzyściami (zob. np. ISJP, USJP, WSFM-N).

Punkt wyjścia naszych rozważań stanowi wyrażenie miłość własna, którego znaczenia poszukujemy, odwołując się nie tylko do własnej intuicji językowej, lecz także do bogatych materiałów źródłowych: a) danych słownikowych zgromadzonych zarówno w słownikach współczesnych, jak i słownikach dawnej polszczyzny, w tym słownikach autorów (zob. zwłaszcza część 3; por. Bibliografia); b) materiałów korpusowych, zgromadzonych w Korpusie Barokowym (KorBa) oraz Narodowym Korpusie Języka Polskiego (NKJP); c) zbiorze tematycznym, obejmującym wybrane przez nas z prasy i Internetu (wyszukiwarka Google) teksty na temat miłości własnej. Dominuje tu zatem perspektywa semazjologiczna, ale biorąc pod uwage hasła definicyjne i wyrazy bliskoznaczne oraz ekwiwalenty tekstowe miłości własnej, włączamy również do analizy spojrzenie onomazjologiczne. Nie ograniczamy się przy tym do badania współczesnego rozumienia interesującego nas pojęcia, staramy się bowiem poznać także jego początki i rozwój. Trzeba jednak zaznaczyć, że koncentrujemy się w tym artykule na semantyce jednego wyrażenia: miłość własna, pozostawiając do innego opracowania dzieje całego pola i dokładniejszą analizę środków językowych, które mogły wyrażać podobne znaczenia przed utrwaleniem tego wyrażenia w dawnej polszczyźnie. Chcąc sprawdzić możliwość oddziaływania języka specjalistycznego (psychologicznego) na potoczne rozumienie interesującego nas pojęcia, w części 4 przyglądamy się z lotu ptaka, czy i jak psychologowie odnoszą się do kategorii miłości własnej. Natomiast w części 5 wychodzimy od naszkicowania dotychczasowego stanu badań semantycznych nad interesującym nas wyrażeniem, a następnie koncentrujemy się na prezentacji językowego obrazu miłości własnej utrwalonego w polszczyźnie. Analizując kolokacje i szersze konteksty wyrażenia miłość własna zarejestrowane w NKJP, wykorzystujemy kognitywną teorię metafory i metonimii pojęciowej (zob. Lakoff, Johnson 1988; Kövecses 1986; 1998, 2011; Jäkel 2003) oraz etnolingwistyczną koncepcję językowego obrazu świata (zob. np. Bartmiński 2006).

\section{Dwa rozumienia miłości własnej}

Kierując się intuicją językową, a także sposobem obrazowania tego pojęcia (o czym będzie mowa później), możemy przypuszczać, że współcześnie dominuje rozumienie miłości własnej, które można opisać jako 'nadmierne poczucie własnej wartości (pragnienie bycia kimś ważnym, wielkim) i potrzeba (pragnienie) potwierdzania tej wartości ze strony innych ludzi', o czym świadczą użycia typu: 
(1) (...) ludzkie spojrzenie pisarza, oślepione miłością własną (...) (Gretkowska M., 2001, Polka - NKJP 10).

(2) (...) granicząca z patologią nieposkromiona miłość własna (...) skłaniająca człowieka do działania, nieraz zbrodniczego (Tomkowski J., 2009, Ciemne skrzydła Ikara. Eseje o rozpaczy - NKJP 148).

Tak rozumiana postawa oceniana jest przez mówiących negatywnie, stąd będziemy ją dalej określać jako negatywne rozumienie miłości własnej. Potwierdzają je też konteksty, zwłaszcza o charakterze religijnym, w których mówi się o potrzebie zwalczenia miłości własnej, uwolnienia się od niej czy wyzbycia się jej.

Jednakże istnieją również wypowiedzi, głównie o charakterze refleksyjnym, w których miłość własna rozumiana jest neutralnie - wbrew powyższemu negatywnemu obrazowi - jako pewien fenomen psychiczny, właściwość przysługująca każdemu człowiekowi, będąca podstawą jego normalnego rozwoju: „(...) realizowanie dobrze pojętej miłości własnej [jest] czynnikiem wspomagającym (...) rozwój [duchowy]” (Skowroński A., 2004, Droga rozwoju, „Głos Ojca Pio” IV - NKJP 77). Także psychologowie współcześni mówią o miłości własnej jako o stanie pozytywnym, umożliwiającym normalny stosunek do innych ludzi: „(...) bez miłości własnej nie doświadczymy jej [miłości] w żadnej relacji, ani nie obdarzymy nią nikogo”. To słowa współczesnego psychologa o potrzebie zrozumienia i zaakceptowania siebie (Nowakowska A., 2012, Miłość własna, „Zwierciadło", 25 IX).

Za tym, że miłość własna ma także to drugie neutralne znaczenie, tzn. odnosi się do neutralnego stanu psychicznego, opisanego wyżej, przemawia kilka względów:

a) Dowodzą tego określenia typu: wybujała, nadmierna, chorobliwa miłość własna, które zakładają istnienie „normalnej”, „właściwej”, „zdrowej” miłości własnej, przy której człowiek ocenia siebie we właściwych proporcjach, zgodnie ze stanem obiektywnym.

b) Kolejnego argumentu dostarczają wypowiedzi oddające refleksję nad pojęciem 'miłości własnej', rozumianej jako obiektywny fenomen psychiczny, przysługujący każdemu człowiekowi, oceniany neutralnie, a nawet pozytywnie. Oprócz wspomnianych wyżej psychologów na temat roli miłości własnej w życiu człowieka wypowiadają się filozofowie, a także inni myśliciele i poeci ${ }^{1}$. Szczególnie interesujące są w tym kontekście rozważania Czesława Miłosza (1996), który wyróżnia obydwa typy miłości własnej: „egoistyczną” i „prawdziwą”. Pisze on:

1 Spośród językoznawców takie pozytywne rozumienie 'miłości własnej' reprezentuje Zofia Zaron (1985), która utożsamia to pojęcie z 'miłością do siebie', akceptacją siebie jako osoby, umożliwiającą przeżycie szczęścia (zob. dalej - cz. 5). 
(3) Zastanawiałem się dość często ostatnimi czasy nad wymową ewangelicznego przykazania o miłości bliźniego - „kochaj bliźniego swego, jak siebie samego”. (...) Powie ktoś, że kochać siebie to znaczy być z siebie zadowolonym. Ale to nie to. (...) Podobna miłość wydaje mi się stałym usposobieniem wewnętrznym, które pozwala zrozumieć, że moja osobowość jest aktem twórczym, wartością jedyną, której miarę taką czy inną, mniejszą czy większą, tylko ja mam zrealizować. Pycha, duma, egoistyczna miłość własna każą nam poszukiwać wyrazu dla naszej osobowości ponad nasz stan i powyżej naszych możliwości. Mierzymy siebie miarą osiągnięć innych ludzi. Chcemy zaspokojenia, które można by nazwać społecznym. Tymczasem habitus prawdziwej miłości własnej znajduje zaspokojenie w porządku wyższym, bo wynikającym $\mathrm{z}$ ogarnięcia ładu całego istnienia, nie jego fragmentów poszczególnych (...) (Cz. Miłosz, 1996, Legendy nowoczesności: eseje okupacyjne - NKJP 43).

To widzenie swojej miary i realizowanie swojego powołania (według własnej miary) ujmuje Miłosz w perspektywie ogarniającej całość świata, całość istnienia. Taka perspektywa znosi dramatyczną antynomię, jaka powstaje między jedynością, niepowtarzalnością, wyjątkowością własnego ‘ja’ a świadomością, że jest się „cząstką” Wszechświata. Przejmująco mówi o tym wiersz Miłosza Miłość:

(4) Miłość to znaczy popatrzeć na siebie,

Tak jak się patrzy na obce nam rzeczy,

Bo jesteś tylko jedną $\mathrm{z}$ rzeczy wielu.

A kto tak patrzy, choć sam o tym nie wie,

Ze zmartwień różnych swoje serce leczy,

Ptak mu i drzewo mówią: przyjacielu (...).

(Miłosz Cz., 1945, z tomu Ocalenie)

Bez tej perspektywy, przywracającej harmonię ze światem, człowiek, czując swoją wyjątkowość, może ulec pokusie postrzegania siebie jako centrum świata, kogoś, komu wszystko wolno, a taka postawa jest groźna dla innych i dla całego świata.

Podobną myśl wypowiada ks. Tadeusz Fedorowicz, duszpasterz Lasek, który jedno ze swoich żartobliwych „Błogosławieństw” formułuje następująco:

(5) Szczęśliwi, którzy wreszcie odkryli swoją miłość własną i nadal chcą ją odkrywać - będą szybko wzrastać w prawdziwej miłości (ks. T. Fedorowicz, Błogosławieństwa dla tych, którzy mają trochę zmysłu humoru i szukaja mądrości; http://www. joga-joga.pl/pl157/teksty 1906/szczesliwi_ktorzy_ks_tadeusz_fedorowicz).

Wers ten zdaje się sugerować, że odkrycie prawdy o sobie, swoich możliwościach i ograniczeniach, o swoim powołaniu i swojej wartości, a także akceptacja siebie i prawdy o sobie, umożliwiają rozumienie i miłość innych ludzi („wzrastanie w prawdzie i miłości”). 
Dodajmy jeszcze na koniec tej części refleksję innego poety. Piotr Matywiecki tak opisuje poczucie własnej tożsamości (jedyności, niepowtarzalności), która stanowi niezbędny składnik pojęcia miłości własnej:

(6) Czym innym [niż tożsamość narodowa] jest tożsamość podstawowa, związana $z$ poczuciem własnego „ja”. Czy jest ono moim charakterem, a może sumą wszystkich relacji ze światem, przyrodą i społeczeństwem? A może, jak mawiają chrześcijanie, tożsamość jest związana z duszą? (Matywiecki P., rozm. A. Gruszczyński, 2018, Rozpamiętanie, „Tygodnik Powszechny”, nr 21, 14 V, s. 80).

Pytanie, na czym polega moja odrębność, jedyność, niepowtarzalność należy do fundamentalnych pytań związanych ze świadomością siebie i jest założone w pojęciu 'miłości własnej'2.

Kończąc nasze wstępne rozważania o dwóch sposobach rozumienia wyrażenia miłość własna spróbujmy sformułować ich hipotetyczne eksplikacje:

a) rozumienie neutralne: miłość własna : 'stan psychiczny człowieka, na który składają się:

- poczucie własnej odrębności, tożsamości, niepowtarzalności;

- akceptacja siebie (uczucie przywiązania do siebie);

- pragnienie tego, co dobre, dla siebie;

2 Na istotną rolę owego poczucia własnej odrębności wskazują m.in. następujące przykłady z NKJP, które równocześnie świadczą o różnym stosunku podmiotu do siebie i roli jego wyobrażenia o sobie:

a) Każdy z tych poszczególnych oddziałów tworzył się początkowo z zamiarem przejścia do regularnego wojska polskiego, połączenia się z którymkolwiek z trzech oficjalnie istniejących korpusów. Mało któremu jednak udało się to (...). Pewną rolę niewątpliwie grała (...) miłość własna młodziutkich dowódców. Każdy z nich w zakresie swojego rejonu czuł się pewną wielkością, samodzielnym wodzem, a wiedział, że przeszedłszy do regularnego wojska, spadnie z wyżyn naczelnictwa do roli małego pionka. Więc nie tracąc sprzed oczu owej idei jako zasadniczego celu uformowania oddziału, odkładał jej wykonanie z dnia na dzień, aż było za późno: Niemcy przyszli, wszelki przemarsz wojsk został surowo wzbroniony, a wszystkie luźne formacje nie wchodzące w skład I albo III Korpusu ogłoszono jako bandy wyjęte spod prawa (Z. Kossak, 1922, Pożoga, PAX, książka fakt - NKJP, 140).

b) Trzeba już pisać, jakby każda książka była ostatnią. Nic nie napisałam z tego, co wiem, co przeżyłam - zachwyt człowiekiem i niszcząca miłość własna, wysuszający interes własnej ambicji - tęsknoty ogromne, niezadowolenie z siebie, straszny zawód, że się jest tylko tym, czym się jest (A. Kowalska, 2008, Dzienniki 1927-1969, Wydawnictwo Iskry, książka fakt - NKJP 152).

c) Rozwój życia Bożego w nas hamują nie tylko grzechy, ale również niedoskonałości, przywiązania, których często nie dostrzegamy. Nie zauważamy, jak bardzo jesteśmy skupieni na sobie, w miejscu należnym Bogu stawiamy własne ,ja”, któremu chcemy wszystko i wszystkich podporządkować. Nie liczymy się z Bożym planem, ale ulegamy temu, co schlebia miłości własnej, daje poczucie ważności, nie zależności. Nawet przystępowanie do sakramentów świętych - spowiedzi, Komunii Świętej - można wykorzystać do budowania dobrego mniemania o sobie i przekonania, że na pewno Bóg jest z nas zadowolony (K.H. Szczurek, 2008, Katolicka nauka o czyśćcu i formy niesienia pomocy zmarłym, Edycja Świętego Pawła, książka nklas. - NKJP 100). 
- przeżycie wartości swojej osoby (i potrzeba zaakceptowania jej przez innych)';

b) rozumienie negatywne: miłość własna : 'stan psychiczny człowieka, na który składają się:

- poczucie własnej odrębności, tożsamości, niepowtarzalności;

- (nadmierne) uczucie przywiązania do siebie;

- pragnienie tego, co najlepsze (wyłącznie) dla siebie;

- przeżycie nadmiernie wysokiej (w stosunku do realnej i/lub uznanej przez otoczenie) wartości (wielkości) swojej osoby lub pragnienie bycia kimś ważnym (wielkim) oraz potrzeba potwierdzania tej wielkości przez innych'.

Wariant drugi cechuje się większą emocjonalnością, przejawiającą się m.in. w ostrym reagowaniu emocjonalnym na brak akceptacji ze strony otoczenia, na negatywnym reagowaniu na pochwały skierowane do innych, również w podatności na zranienia, w pragnieniu bycia ważnym przy niepewności co do własnej wartości (stąd w ostatnim punkcie wprowadzamy alternatywę). Wreszcie postawa opisywana przez miłość własną 2 jest oceniana negatywnie przez mówiących, co uwidocznia się w konceptualizacji i obrazowaniu wariantu negatywnego. Zanim jednak dojdziemy do tych kwestii, przyjrzyjmy się rozwojowi tego pojęcia i wyrażenia w dziejach polszczyzny.

\section{Miłość własna w perspektywie historyczno-leksykograficznej}

\subsection{Analiza danych słownikowych oraz korpusu tekstów dawnych}

Połączenie miłość własna jako wyrażenie stabilizujące się w języku pojawia się w polszczyźnie stosunkowo późno, bo dopiero w XVII wieku. Linde, który jako pierwszy słownikarz odnotował to wyrażenie (w definicji miłości ku sobie i w szeregu synonimicznym z samolubstwem), podaje jego realizacje w różnym jeszcze szyku - i są to przykłady z XVII i XVIII w.:

(7) Miłość własna nie ma żadnego przyjaciela. Cn. Ad. 502 (L, t. 3, s. 115).

(8) Własna miłość sądzi być zbawiennym dla dobra powszechnego, co jej żądzom pochlebia. Boh. Zamoj. 35 (L, t. 3, s. 115).

Połączenie miłość własna mimo nieobecności w słownikach dawniejszej polszczyzny ${ }^{3}$ ma wyraźne poświadczenia w Korpusie Barokowym (24 użycia).

3 Słowniki polszczyzny do XVIII w. (SStp, SPXVI, SJK, SJPXVII, SJChP) nie notują miłości własnej. Ale w dwóch z nich (SPXVI i SJPXVII) wymieniono konstrukcje: miłość samego siebie, miłość ku sobie, definiowane przez amor sui, wszystkie z oceną negatywną. 
Określany tym wyrażeniem stan psychiczny człowieka jest tam wartościowany negatywnie w dyskursie religijnym - jako przeciwieństwo duchowości i posłuszeństwa wobec Boga, przez skojarzenie z grzechem, zmysłowością i podatnością na opinie innych, a w kontekstach pozareligijnych - jako przeciwieństwo zdrowego rozumu, bo obejmuje nieracjonalną ocenę własnych możliwości, potrzeb i dokonań. Pokazują to przykłady:

(9) Jeszcze Boże mój dla pokoju serca mego/ chcę wszytkie zrzodła/ korzenie i początki niepokojów/ niezgód/ i mieszanin/ w-sobie częścią wykorzeniać i znosić/ częścią miarkować/ jakie są miłość własna/ która zaślepia człowieka/ własny uporny rozum/ i rozsądek/ własna także wola i swoje przewodzić chcąca abo nałożna; więc też i popędliwość namiętności: a naostatek respekty ludzkie/ abo chcenie wygodzić ludzkim fantazjom i mowom/ chcenie uchronić się ludzkich przymówek/ chcenie podobać się abo więc zrównać innym (K. Drużbicki, 1665, Droga doskonałości chrześcijańskiej - KorBa 6).

(10) Czemu prędzej cudzą wadę widziemy niż nasze? Bo w cudzych rzeczach wolny mają rozsądek od namiętności, zdrowo rozsądzany, (...) a w rzeczach naszych miłość własna tak nam rozum mięsza iż nam się i to podoba, czego by się wstydzić trzeba (W. Tylkowski, 1692, Uczone rozmowy - KorBa 8).

Cennego świadectwa XVIII-wiecznego rozumienia miłości własnej dostarcza traktat poświęcony temu pojęciu autorstwa Józefa E. Minasowicza ${ }^{4}$ O przyczynie namiętności ludzkich, drukowany w „Monitorze” w 1771 r. (w 13 zeszytach). Według autora źródłem miłości własnej był grzech Adama, który wprowadził nieporządek w naturę człowieka i poprzez „wylężenie miłości własnej” zapoczątkował wszelkie pożądliwości i namiętności ${ }^{5}$. Człowiek bowiem przez grzech pierworodny postawił swoją wolę i swoje pragnienia na pierwszym miejscu, ignorując Boga. Wynikłe z tego namiętności wymagają, zdaniem Minasowicza, kontroli i ukierunkowania pod wpływem łaski Bożej - co może wprawdzie czynić je pozytywnymi (np. „nienawiść do grzechu”), ale nieopanowane i nieukierunkowane są zawsze złe (np. „nienawiść do ludzi”, rodząca okrucieństwo, czy „boleść duszy”, wypływająca z rozmiłowania się we własnym smutku) (Minasowicz 1771; por. Marcinów 2017).

Zatem pod koniec XVIII wieku, a więc na początku doby nowopolskiej, mamy do czynienia z dążącą do ustabilizowania formą i znaczeniem wyrażenia miłość własna, które najogólniej wskazuje na 'nieaprobowane (wysokie/nadmierne)

4 Józef Epifani Minasowicz (1718-1796), wydawca, tłumacz, poeta i publicysta, ukończył studia prawnicze, bliski współpracownik Józefa Andrzeja Załuskiego.

5 Lista owych „namiętności” obejmuje: miłość, nienawiść, nadzieję, rozpacz, śmiałość (odwagę), bojaźń (strach), gniew, ukontentowanie (zadowolenie), boleść (ból, smutek), żądzę i zazdrość. 
poczucie własnej wartości i pragnienie (potrzebę) uznania jej ze strony innych ludzi'. Zauważmy przy tym, że wyrażenie to mogło utrwalić się w polszczyźnie pod wpływem języka francuskiego - jako kalka popularnego w XVII i XVIII w. wyrażenia amour-propre, które, dodajmy, zostało zapożyczone - już bezpośrednio - także do języka angielskiego (OED odnotowuje je po raz pierwszy w tekście angielskim powstałym w $1775 \mathrm{r}$. $)^{6}$.

Spójrzmy na dalsze losy tego pojęcia w polszczyźnie i jego rozumienie współczesne.

\subsection{Analiza danych słownikowych doby nowopolskiej}

Opracowania leksykograficzne XIX, XX i XXI wieku odnotowujące związek miłość własna nie są zgodne co do zawartości i liczby jego znaczeń. Analiza dwudziestu słowników pokazuje, że w dziesięciu z nich, obejmujących materiał od XIX w., zdefiniowano interesujący nas związek i to na trzy różne sposoby:

a) Dwa słowniki: warszawski (z przełomu XIX/XX w.) i frazeologiczny Müldnera-Nieckowskiego (z początku XXI w.), podają, podobnie do naszej wstępnej propozycji eksplikacyjnej, dwa znaczenia miłości własnej: 1) neutralne (lub pozytywne) (wg Müldnera-Nieckowskiego ograniczone do użyć psychologicznych): 'naturalne przywiązanie do własnej osoby, poczucie własnej wartości, szacunek dla siebie, akceptacja własnej osoby’ [SW, s. 998; WSFM-N, s. 400], oraz b) negatywne: 'samolubstwo, egoizm, myślenie i działanie wyłącznie ze względu na własną korzyść' [SW, s. 998; WSFM-N, s. 400]. Zauważmy, że już przykłady XIX-wieczne, a mianowicie fragmenty $\mathrm{z}$ tekstów A. Mickiewicza, ujawniają tę ambiwalencję i dwuznaczność miłości własnej - z jej pozytywnym rysem włącznie, np.: „miłość własna nie dozwala mi być słabą ofiarą okoliczności” (SAM, t. IV, s. 35).

b) Dwa z najnowszych słowników - ISJP i USJP - ograniczają się do znaczenia negatywnego, intuicyjnie najbardziej się narzucającego: 'nadmiernego poczucia własnej wartości’ [z synonimami: (nadmierna) ambicja oraz duma] (zob. ISJP, USJP).

c) Pozostałe wskazują na neutralne: 'poczucie własnej wartości' (PSWPZgółk; SJPSz dodaje synonim: ambicja) czy 'przywiązanie do własnej osoby, cenienie swojej wartości’ (SJPD i SFraz również dołączają jako synonim

6 Dziękujemy Uczestnikom konwersatorium „Dociekania semantyczne” (tzw. śród semantycznych, organizowanych na Wydziale Polonistyki Uniwersytetu Warszawskiego) oraz Davidowi Stephensonowi za zwrócenie uwagi na możliwość wpływu języka francuskiego na upowszechnienie pojęcia 'miłości własnej' w innych językach, w tym także w polszczyźnie. 
ambicję) albo 'kochanie siebie' (SWil). WSJP zwraca dodatkowo uwagę na element wolicjonalny: 'potrzebę podmiotu bycia docenionym'.

Rozbieżności są zatem znaczące, choć łącznie można mówić o czterech domenach przywoływanych $\mathrm{w}$ tych opisach: domenie WARTOŚCIOWANIA (samooceny), WOLI (potrzeb), UCZUĆ: MIŁOŚCI (przywiązania) i RELACJI MIĘDZYLUDZKICH (Ja wobec innych).

W tym kontekście warto sprawdzić, jak odnoszą się do zjawiska opisywanego przez miłość własną psychologowie.

\section{Miłość własna w ujęciu psychologicznym (zarys)}

Artur Reber w Słowniku psychologicznym (2000) włącza miłość własną do terminów psychologicznych ${ }^{7}$ i:

a) po pierwsze, uznaje opisywany przez to wyrażenie stan za jeden $z$ rodzajów miłości, czyli zalicza go do kategorii UCZUĆ, i wraz z innymi „przejawami miłości”, np. miłością do dziecka, opisuje jako wyraz „podstawowej siły instynktownej" (Reber 2000, s. 372);

b) po drugie, w definicji hasła miłość własna zawęża jego znaczenie do 'skrajnych postaci miłości do samego siebie', eksponując bardzo duże lub nadmierne nasilenie tego stanu (Reber 2000, s. 373);

c) po trzecie zaś, poprzez odsyłacze wskazuje na pokrewieństwo miłości własnej i narcyzmu oraz egoizmu, a pośrednio także egotyzmu.

W eksplikacji narcyzmu Reber profiluje zewnętrzną negatywną ocenę nadmiernie nasilonej miłości własnej. Jednak Anna Tylikowska (zob. dalej przykład 12) uznaje takie znaczenie za właściwe użyciom potocznym, czemu przeciwstawia znaczenie psychologiczne: „skupienie na sobie wynikające z braku jasno określonego Ja, [z] niezaspokojenia istotnych potrzeb”, czego źródłem jest nieznajomość własnych możliwości i ograniczeń, a następstwem - potrzeba wzmacniania Ja przez wyrazy uznania ze strony innych (zob. Tylikowska 2018). Psychologowie wyodrębniają też pokrewną narcyzmowi osobowość narcystyczną i jej odmiany, które traktują jako zaburzenia osobowości (zob. Reber 2000, s. 398; Tylikowska 2018).

Podobnie egoizm, zdaniem Rebera, rozumiany ogólnie jako 'zainteresowanie samym sobą, może w psychologii sygnalizować dwa znaczenia: a) pierwsze, bardziej specjalistyczne, uznające cechę egoizmu za przeciwieństwo altruizmu,

\footnotetext{
7 Jednak ani Bogdan Wojciszke (2005), polski badacz miłości i przywiązania, ani autorzy rozdziału poświęconego miłości w Psychologii emocji (Elaine Hatfield i Richard L. Rapson 2005), ani też Michael Lewis (2005a, 2005b), znawca emocji samoświadomościowych, nie uwzględniają kategorii miłości własnej w swoich pracach.
} 
podstawę wszelkich zachowań - warunek przetrwania; b) drugie, tożsame z rozumieniem potocznym (co potwierdzają współczesne słowniki: ISJP, USJP i WSJP) - za skłonność do zachowywania się motywowanego osobistymi korzyściami, z instrumentalnym traktowaniem innych włącznie (Reber 2005, s. 179; por. Tylikowska 2018) ${ }^{8}$.

Wskazane terminy - zwłaszcza narcyzm, egoizm i im pokrewne - są przywoływane w kontekście miłości własnej we współczesnych tekstach z zakresu psychologii „praktycznej”, popularyzowanej w poradnikach psychologicznych, w prasie i Internecie, na przykład:

(11) (...) sologamia (...) ślub z samym sobą (...).

Czyli mamy tu do czynienia z przejawem egocentryzmu?

Nie oceniałabym tego tak jednoznacznie. Jestem pełna pozytywnych uczuć dla osób, które przechodzą przez ten rytuał miłości własnej. Zgadzam się, że nie potrzebujemy drugiej osoby, by czuć się kompletni, pełni, wartościowi. Możemy, a nawet powinniśmy kochać samych siebie (Z B. DePaulo rozmawia D. Graba, 2018, I ślubuję SOBIE, „Charaktery”, III, s. 34).

(12) NARCYZM jest, w sensie potocznym, nadmierną, bezkrytyczną miłością własną. W rozumieniu psychologicznym jest czymś nieomalże przeciwnym - skupieniem na sobie wynikającym z braku jasno określonego Ja, niezaspokojenia istotnych potrzeb. Nasilony, przyjmuje postać tzw. narcystycznego zaburzenia osobowości, wyrażającego się m.in. wyolbrzymionym poczuciem własnego znaczenia i wyjątkowości, brakiem empatii, wykorzystywaniem innych do własnych celów, arogancją. Narcystyczne skoncentrowanie na sobie, roszczenia, manipulacje i fantazje mają bolesne drugie dno: są typowe dla osób, które w dzieciństwie nie miały możliwości poznania swoich możliwości i ograniczeń, więc nie wiedzą, kim są, do tego stopnia, że podtrzymują swoje kruche Ja dzięki admiracji ze strony innych - i są w tym nienasycone, bo nie wiedzą, jak się nasycić (A. Tylikowska, 2018, „JA”, czyli kto? Człowiek w Egolandii. Krótka historia JA i pojęć pokrewnych, „Ja, My, Oni. Poradnik Psychologiczny”, „Polityka”, t. 30: „Do czego nam EGO”, 15 V - https://www.polityka.pl/jamyoni/ 1747974,1,ja-czyli-kto.read).

(13) Miłość własna nie jest samolubstwem (...). Miłość własna jest stanem samooceny, która wyrasta z działań jakie wspierają nasze fizyczne i psychiczne zdrowie oraz stymulują nasz duchowy wzrost. Miłość własna jest dynamiczna.

8 W definicji egotyzmu natomiast na pierwszy plan wysuwa się element aksjologiczny: bardzo wysoka pozytywna samoocena podmiotu, połączona z nadmiernym „kierowaniem na siebie uwagi otoczenia” (co sygnalizuje Tylikowska) i negatywna ocena zewnętrzna ze strony tegoż otoczenia wpisana w przeżycie irytacji (co podkreśla Reber); w charakterystyce pokrewnego egocentryzmu zaś - zawężenie uwagi podmiotu do samego siebie i ograniczenie wrażliwości na innych (Reber 2000, s. 179, 180; por. Tylikowska 2018). Ze względu na brak miejsca eksplikacje egoizmu, egocentryzmu i egotyzmu stosowanych w języku niespecjalistycznym zostawiamy do odrębnego opracowania. 
Rośnie dzięki działaniom, które sprawiają, że dojrzewamy. Kiedy działamy w taki sposób, że rozszerzamy w sobie miłość własną, zaczynamy lepiej akceptować nasze słabości i mocne strony. (...) Pozwala nam to skupić się bardziej na naszym celu i na wartościach. (...) Ludzie o większej miłości własnej zazwyczaj wiedzą, co myślą, czują i czego pragną. Są świadomi tego, kim są (...). Nie zachowują się zgodnie z tym, czego chcą dla nich lub od nich inni. (...) Nie możesz kochać innej osoby bardziej niż siebie samego. Dlatego musimy nauczyć się kochać samych siebie, aby móc oferować miłość innym (Miłość własna to żadne samolubstwo, 24 II 2018; Miłość własna - jak ją zwiększyć przy pomocy 7 prostych kroków, 7 I 2018 - wpisy na blogu: „Piękno Umysłu”: https://pieknoumyslu.com/).

Co istotne, w tekstach tych widać wysuwającą się na plan pierwszy nie negatywną ocenę miłości własnej ( $\mathrm{z}$ czym kojarzone są tu narcyzm, egoizm czy egocentryzm, a także potoczne: samolubstwo), ale ocenę pozytywną. Miłość własna jest tu bowiem opisywana jako pożądany stan, obejmujący świadomość podmiotu swoich zalet i ograniczeń, akceptację siebie, szacunek do siebie połączony z dostrzeganiem wartości innych i szacunkiem do nich, bez uzależniania się od zewnętrznych opinii i presji otoczenia - i jest to stan uznawany za warunek rozwoju jednostki oraz warunek miłości do innych. Podobną zmianę wartościowania między XVIII a XXI w. opisała w języku rosyjskim Elena Berezovicz na przykładzie analizy znaczenia leksemu samolubie (zob. Berezovicz 2013) ${ }^{9}$.

Warto przy tym zauważyć, że narcyzm, egoizm i egocentryzm zdają się przenosić z tekstów psychologicznych do kontekstów ogólnych perspektywę naukowego lub psychoterapeutycznego dystansu, opisując wyraźnie z zewnątrz cechy osobowości człowieka -w przeciwieństwie do miłości własnej, która koncentruje się na oddaniu wewnętrznego stanu podmiotu.

\section{5. 'Miłość własna' we współczesnej polszczyźnie - stan badań i obrazowanie}

O rozumieniu miłości w języku polskim i innych językach lingwiści napisali już wiele (co przykładowo pokazuje Bibliografia), jednak pojęcie 'miłości własnej' albo nie pojawia się w ich pracach w ogóle (np. w: Kocha - lubi - szanuje.

To, co możemy obserwować, śledząc historię pojęć takich jak 'miłość własna’ w polszczyźnie czy 'samolubie' w języku rosyjskim, pozostaje więc w zgodzie z obserwowanymi przez psychologów ogólnymi zmianami w zakresie systemów wartości i ideałów uznawanych przez społeczeństwa w różnym czasie. Zarysowujący się od wieku Oświecenia rozkwit indywidualizmu (wcześniej tłumionego, zwłaszcza w średniowieczu), wspomagany przez romantyczne dowartościowanie osobistych przeżyć, doprowadził do powstania w myśli psychologicznej XIX w. koncepcji JA/EGO (zob. Tylikowska 2018) i okazuje się zbieżny z rozwojem pojęcia ‘miłości własnej' w polszczyźnie. 
Medytacje semantyczne Anny Wierzbickiej 1971), albo jest traktowane wybiórczo (np. przez Zofię Zaron 1985 i Aldonę Zwierzyńską 1992), albo schodzi na margines (np. u Marii Głąbskiej 2014).

Dla przykładu w najnowszej ze wspomnianych prac Maria Głąbska, która badała rozumienie miłości w polszczyźnie na podstawie analizy znaczeń leksemów miłość i kochać, wyrażenie miłość własna usunęła z pola widzenia jako niepowiązane z kategorią UCZUĆ, bo opisujące 'nadmierną ambicję i wygórowane poczucie własnej wartości' - zgodnie z sugestią ISJP. Równocześnie jednak ta sama autorka połączenia miłość do siebie i kochać siebie uznała za odsyłające do kategorii MIŁOŚCI i opisała jako dwuznaczne - mówiące o nadmiernym egoizmie, ocenianym negatywnie, lub o samoakceptacji, ocenianej pozytywnie (zob. Głąbska 2014, s. 49, 58-59).

Trzydzieści lat wcześniej Zofia Zaron natomiast zawęziła rozumienie miłości własnej do znaczenia pozytywnego, opartego na samoakceptacji, traktując przy tym połączenia: miłość własna i miłość samego siebie oraz kochanie siebie samego jako obejmujące to samo pojęcie (zob. Zaron 1985, s. 43-48). Autorka, odwołując się do własnej intuicji językowej i refleksji filozoficznej (Arystotelesa, św. Tomasza z Akwinu, św. Augustyna), uznała, że miłość własna nie jest „niczym innym jak pragnieniem szczęścia”, które jest „warunkiem osiągnięcia pełni własnego istnienia" (Zaron 1985, s. 44), a jako pomyłkę potraktowała utożsamianie miłości własnej z egoizmem, odrzucając jej negatywne rozumienie (Zaron 1985, s. 43-44). W efekcie zaproponowała definicję postulatywną pozytywnie postrzeganej miłości własnej, ujętą w formę eksplikacji połączenia: X kocha siebie samego ${ }^{10}$. Co więcej, miłość własna została tu potraktowana jako jeden z rodzajów miłości, stanowiący „miarę i źródło [wszelkiej - R.G., A.M.] miłości” (Zaron 1985, s. 44).

Jeszcze inne podejście znajdujemy w artykule Aldony Zwierzyńskiej, która zbadała porównawczo wyidealizowane modele kognitywne pojęć 'miłość' i 'love' utrwalone w przysłowiach polskich i angielskich (Zwierzyńska 1992). Autorka opisała rozumienie 'miłości własnej'/'self-love' jako znaczenie peryferyjne wobec modelu centralnego MIŁOŚCI / LOVE, opartego na centralnej metaforze pojęciowej MIŁOŚĆ TO JEDNOŚĆ. Jak argumentowała, ze względu na brak niektórych ważnych dla modelu centralnego cech miłości w rozumieniu miłości własnej (np. fakt, że podmiot jest tu obiektem swoich przeżyć, co zaprzecza modelowi interakcyjnemu, wpisanemu w metaforę centralną), pojęcie miłości uzyskuje tu „z reguły negatywny wydźwięk”, czego dowodzą przysłowia: Miłość własna nie ma żadnego przyjaciela oraz Żadna jarzyna tak nie odyma jak miłość

10 Eksplikacja ta ma następującą postać:

„X kocha siebie samego. / $Y=X / \approx X$ wie, że jest szczęśliwy, że jest Osobą/istnieje dla siebie samego / i X wie, że chce być Osobą / i X czuje, że jest jednością”. (Zaron 1985, s. 47). 
własna - wskazujące na „społecznie naganny” „brak pozytywnych relacji jednostki z otoczeniem" (Zwierzyńska 1992, s. 107) ${ }^{11}$.

W kontekście dotychczasowych propozycji semantyków pojawia się zatem pytanie, czy współcześnie należy/da się ostro oddzielić od siebie miłość własna i miłość do siebie oraz czy powinno się zawężać znaczenie tego pierwszego wyrażenia do jednego tylko ze wskazywanych przez nas wcześniej wariantów: negatywnego lub neutralnego/pozytywnego.

Pamiętając o wspomnianych wyżej rozbieżnościach w semantycznej interpretacji wyrażenia miłość własna (a wcześniej także w opisach leksykograficznych - zob. cz. 3.2.), postanowiłyśmy sprawdzić na materiale tekstowym, jakie obrazowanie miłości własnej jest wykorzystywane przez różnych użytkowników polszczyzny i z którymi wariantami znaczenia się ono wiąże. Narodowy Korpus Języka Polskiego (w wersji zrównoważonej) rejestruje tylko 203 przykłady użycia tego wyrażenia ${ }^{12}$, co jednak pozwala na wskazanie kilku mniej lub bardziej powtarzalnych sposobów metaforycznego (i metonimicznego) obrazowania miłości własnej w polszczyźnie (specyficznych także w porównaniu z pokrewnymi pojęciami: ambicji, dumy i godności - z których dwa pierwsze są przywoływane m.in. przez leksykografów w definicjach miłości własnej).

$\mathrm{W}$ analizowanym materiale językowym miłość własna jawi się często jako wyolbrzymiona, maksymalnie wartościowana osoba (Ja), odrębna od podmiotu i wpływająca na jego zachowania.

1) Bywa więc wyobrażana jako ktoś aktywny, samodzielny, kto - podobnie jak zwierzchnik czy władca - wydaje podmiotowi stanu rozkazy, polecenia i zakazy (tak samo jak ambicja, godność i duma), a nawet steruje nim, utrudniając mu wchodzenie w pozytywne relacje z innymi (odwracając go od Boga i od drugiego człowieka):

MIŁOŚĆ WŁASNA JAKO ZWIERZCHNIK: mitość wtasna każe komuś coś robić, nie daje / nie pozwala komuś czegoś robić; kieruje kogoś przeciwko komuś; odwraca kogoś od kogoś

2) Podmiot może próbować z nią walczyć, ale przezwyciężenie jej nie jest łatwe, jako że miłość własna zastawia pułapki, maskuje się i oszukuje. W efekcie podmiot zazwyczaj jej ulega, uznając jej zwycięstwo. Zauważmy,

11 Pojęcie to - zdaniem autorki - choć nie wchodzi do ICM-u miłości prototypowej, bo jest „oddalone od jądra konceptualnego" pojęcia miłości, to sytuuje się na peryferiach jego znaczenia, a więc nie odrywa się od niego zupełnie, jak to sugerowała M. Głąbska.

12 Jest to niewielka liczba (chociażby w kontekście takich haseł jak egoizm - 1566, czy tym bardziej ambicja, godność i duma - każde powyżej 7000 poświadczeń - oraz miłość - ok. 40000 przykładów w NKJP), ale zbliżona do frekwencji egocentryzmu - 211 i narcyzmu - 264 przykłady w NKJP, co wskazuje na ich ograniczony charakter (i co potwierdza słownikowy kwalifikator: ksiązkowy w USJP i WSFJPM-N przypisany wyrażeniu miłość własna). 
że taka konceptualizacja nie pojawia się w ogóle w przypadku obrazowania godności:

MIŁOŚĆ WŁASNA i JEJ PODMIOT JAKO PRZECIWNICY W WALCE: walka ze starannie zamaskowana miłością własna; na kogoś czyhaja pułapki miłości własnej; ktoś ulega miłości własnej, czyjeś spojrzenie oślepione miłościa własna, zwycięstwo miłości własnej; zapora dla miłości własnej, przezwyciężenie miłości własnej

3) Szczególnie trudno jest oprzeć się miłości własnej mającej bardzo duże nasilenie. Jako taka bywa ona obrazowana m.in. na kształt nadzwyczajnie przerośniętej, wybujałej rośliny, która w sprzyjających warunkach rozkwita jak najpiękniejszy kwiat. Jest to sposób obrazowania dobrze potwierdzony także dla ambicji i dumy, ale nieobecny w konceptualizacji godności:

MIŁOŚĆ WŁASNA JAKO ROŚLINA: wybujała miłość własna; miłość własna rozkwitała jako ta lilia; czyjaś miłość własna urosła

4) Miłość własna (podobnie zwłaszcza jak ambicja, także duma, ale inaczej niż godność) wzmacnia się, jeśli zaspokaja się jej potrzeby, bo - jak sybaryta, człowiek spragniony przyjemności i pochwał - lubi, kiedy się ją karmi, łechce, głaszcze, chwali i kiedy się jej dogadza:

MIŁOŚĆ WŁASNA JAKO SYBARYTA: ktoś zaspokaja / karmi czymś swoją/czyjąś mitość własną; ktoś/coś schlebia / pochlebia czyjejś miłości własnej, ktoś/coś łechce / połechce czyjąś miłość własną, ktoś robi coś dla pogłaskania / dla dogodzenia miłości własnej; rozkosze miłości własnej

5) Może być rozjuszona i nieposkromiona - jak dzikie zwierzę - nie daje się wówczas kontrolować podmiotowi ani jego otoczeniu - podobnie jak ambicja, ale inaczej niż godność czy duma:

MIŁOŚĆ WŁASNA JAKO DZIKIE ZWIERZĘ: rozjuszona / nieposkromiona miłość własna

6) Opisywany stan bywa też konceptualizowany jako część (ciała) (lub ogólniej jako istota cielesna), którą ktoś pielęgnuje, której odruchami jest w stanie kierować - jeśli jej wrażliwość pozostaje w normie (podobnie jak w przypadku godności). Ale nadwrażliwą miłość własną (tak jak zwłaszcza ambicję, niekiedy też dumę) łatwo jest podrażnić, a w skrajnych przypadkach przechodzi ona w stan chorobowy, patologiczny (i jako taka bywa przeciwstawiana zdrowej miłości własnej $\left.{ }^{13}\right)$ :

13 Zob. np.: „Na pewno nie chodzi o wyobrażanie sobie cnót, których się nie ma, ani o pielęgnowanie poczucia samowystarczalności, które wcześniej czy później okazuje się zdradliwe. Polega to raczej na poznaniu wielkości naszej natury: człowiek jest «na ziemi jedynym stworzeniem, którego Bóg chciał ze względu na nie samo»; został stworzony na Jego obraz i podobieństwo, jest 
MIŁOŚĆ WŁASNA JAKO CZEŚŚĆ (CIAŁA) ISTOTY ŻYWEJ (LUB ISTOTA CIELESNA): pielęgnowanie miłości własnej; ktoś jest $w$ stanie kierować odruchami miłości własnej; wrażliwość czyjejś miłości własnej, nadwrażliwa miłość własna, podrażniona miłość własna; chorobliwa / patologiczna miłość własna

7) Wyobrażenie nadwrażliwej miłości własnej przywołuje też typowy dla tekstów współczesnych obraz miłości własnej jako ofiary czyichś ataków. Mamy tu znowu do czynienia z pojęciem istoty żywej, tym razem jednak pasywnej - którą ktoś zranił, uraził, ugodził, która przez to cierpi, sponiewierana, aż do umartwienia:

a) MIŁOŚĆ WŁASNA JAKO OFIARA: ktoś/coś rani/zranit czyjąś miłość własna, zraniona miłość własna; czyjaś miłość własna cierpi, cierpiąca miłość własna; ktoś uraził / ugodził czyjasś miłość własna, urażona miłość własna; sponiewierana miłość własna; nie sposób zrobić czegoś bez umartwienia miłości własnej

Do obrazu zranienia nawiązują także wyrażenia i zwroty, które jako ofiarę napaści przedstawiają sam podmiot miłości własnej - to on może być do głębi zraniony, głęboko dotknięty, urażony albo złamany w miłości własnej:

b) PODMIOT MIŁOŚCI WŁASNEJ JAKO OFIARA: ktoś jest do głębi zraniony / głęboko dotknięty / urażony / złamany w miłości własnej ${ }^{14}$

Zauważmy, że podobne jak w podpunktach (a) i (b) obrazowanie występuje też w konceptualizacji dumy i ambicji oraz godności - pojęć, które łączy wyobrażenie idealnego Ja.

8) Przestrzenna konceptualizacja miłości własnej znalazła zastosowanie w jednostkowych przykładach odwołujących się z jednej strony do wizji WIĘZIENIA, z którego podmiot chce się uwolnić, a z drugiej - do

wezwany do tego, by doprowadzić ten obraz do pełni, utożsamiając się coraz bardziej z Chrystusem przez działanie łaski. To wzniosłe powołanie jest podstawą zdrowej miłości własnej, obecnej w wierze chrześcijańskiej. W świetle tej wiary możemy oceniać nasze osiągnięcia i porażki. Pogodna akceptacja własnej tożsamości wpływa na nasz sposób bycia w świecie i działania w nim. Poza tym buduje pewność siebie, która zmniejsza lęk i nieśmiałość, pomaga otwierać się na innych i na nowe sytuacje, zwiększa optymizm i radość" (J. Cavanyes 2016, Zdrowa miłość wtasna, OPUS DEI - https://opusdei.org/pl-pl/article/zdrowa-milosc-wlasna/).

14 Należy tu jednak podkreślić, że przykłady z grupy (b) stwarzają problemy interpretacyjne. Jeśli próbujemy odnaleźć analogiczne konstrukcje odnoszące się do domeny źródłowej w dosłownych użyciach czasowników typu zranić czy urazić (i ich form imiesłowowych) albo określeń nazywających konsekwencje takiego zranienia (np. odczuwać ból), to z jednej strony mamy połączenia w rodzaju: ktoś zranił / uraził kogoś w kolano/głowę itp. (z nazwą części ciała w bierniku), a z drugiej ktoś odczuwa ból w kolanie / klatce piersiowej itp. (z nazwą części ciała w miejscowniku), ale połączeń typu ${ }^{\star}$ zraniony / urażony w kolanie / głowie / klatce piersiowej itp. nie odnotowujemy, nie ma zatem paraleli między rozumieniem fizycznym a obrazem miłości własnej jako części ciała, w której lokalizowany byłby uraz. 
IZOLATKI, w której dobrowolnie zamyka się przed innymi, odgradzając się od otoczenia:

MIŁOŚĆ WŁASNA JAKO WIĘZIENIE /IZOLATKA: prośba o przebaczenie oznacza szansę wydobycia się z bram więzienia miłości własnej; ktoś zamyka się przed innymi w miłości własnej

W takich przypadkach wyraźnie widać, że miłość własna utrudnia podmiotowi nawiązywanie i podtrzymywanie relacji z innymi ludźmi, czego nie obserwujemy w rozumieniu godności (analogicznych przykładów nie odnotowałyśmy też w korpusowych kolokacjach ani ambicji, ani dumy).

9) W większości przywołanych dotychczas przykładów miłość własna była wartościowana negatywnie. Kiedy jednak mamy do czynienia z wyobrażeniem miłości własnej jako cennego obiektu, na którym komuś zależy, który inni szanują (podobnie jak godność), oszczędzają, którego nie depczą, a którego można, wprawdzie z wysiłkiem, się wyrzec, poświęcić go dla czegoś cenniejszego - miłość własna jawi się wówczas jako coś przynajmniej pod pewnym względem pożądanego. Brak lub deficyt tak rozumianej miłości własnej staje się w tym świetle wadą:

MIŁOŚĆ WŁASNA JAKO CENNY PRZEDMIOT (o wartości utylitarnej): ktoś poświęcił (swoja) miłość własna dla czegoś/czemuś; coś wymaga wyrzeczenia się miłości własnej, komuś najtrudniej zrezygnować z jakiejś postaci miłości własnej; ktoś czyni ustępstwa kosztem swej miłości własnej, ktoś musiał porzucić wszelka miłość własną; ktoś szanuje / oszczędza czyjąs miłość własną; ktoś robi coś, nie depcząc czyjejś miłości własnej; komuś zależy na jego miłości własnej

10) W pozytywnych kontekstach miłość własna jest też ujmowana jako zjawisko trudne do zrozumienia, warte wysiłku poznawczego i nauki (tego typu kolokacje nie zostały odnotowane ani dla godności, ani dla dumy, ani dla ambicji). Żeby dobrze ją pojąć, ktoś, kto nie jest jej znawcą, potrzebuje specjalnego szkolenia albo choćby wyjaśnienia, które ułatwi mu odróżnianie autentycznej, prawdziwej miłości własnej od jej atrap i dublerów, a co za tym idzie, lepsze rozumienie siebie i innych oraz radzenie sobie w życiu $^{15}$. Tego typu obrazowanie może wskazywać na brak jednoznaczności w rozumieniu miłości własnej i wątpliwości z tym związane:

MIŁOŚĆ WŁASNA JAKO PRZEDMIOT POZNANIA i NAUKI: dobrze pojęta miłość własna; ktoś nie zna się na kobiecej miłości własnej; nauka miłości własnej, krótki kurs miłości własnej; autentyczna/prawdziwa miłość własna

15 Pozytywne konsekwencje takiej nauki pokazują m.in. przykłady wypowiedzi rejestrowane na stronach internetowych uwzględniających chrześcijańską wizję świata (zob. np. przypis 11) i daleko odbiegające od tego, co można było obserwować w analogicznym dyskursie sprzed kilku wieków - np. w cytatach Korpusu Barokowego i traktacie Minasowicza. 
Zaprezentowane różne sposoby obrazowania miłości własnej widoczne w przykładach zarejestrowanych w NKJP (i w Internecie) pozwalają na uwypuklenie w wypowiedziach takich aspektów pojęcia MIŁOŚĆ WŁASNA, jak: a) uczestnicy, czyli podmiot stanu (najczęściej pasywny) oraz inni ludzie (lub Bóg): wykluczeni z relacji z podmiotem lub pozostający z nim $\mathrm{w}$ relacji - jako dogadzający mu, zagrażający i/lub go oceniający, oraz b) charakterystyka stanu: jego nasilenie (najczęściej skrajne/nadmierne) oraz wartościowanie (nie tylko negatywne, ale też pozytywne, choć powiązane z wartościami utylitarnymi, nieabsolutnymi). Co ważne, sam podmiot jest prototypowo reprezentowany w tekstach przez człowieka - może nim być każdy (jak w przykładzie 14 poniżej), ale szczególnie predysponowani do niej są ludzie władzy, sztuki, mediów itp. (jak w przykładzie 15), czyli osoby, które „więcej znaczą” w społeczeństwie niż inni (zob. cytat 14). Co ciekawe, cecha nadmiernego poczucia własnej wartości i potrzeby uznania jej przez innych jest przypisywana kilkakrotnie również podmiotowi zbiorowemu - przeważnie jako cecha narodowa Polaków (por. przykład 16):

(14) Nie, to nie ona płacze. To chłopak od praczki, gazeciarz, w swojej kryjówce na dachu oficyny. Widać i jemu się nie wiedzie, choć chciałby dla siebie, tak jak każdy, wszystkiego, co najlepsze. Im mniej kto znaczy, tym bardziej jego miłość własna wyda się wszystkim wokół niestosowna (M. Tulli 2006, Skaza - NKJP 160).

(15) Szczególnego rodzaju „Zwierzęciem”, polski polityk jest, / Znacząco się odróżnia, na tle światowych kolegów. / Myśli, że jest najgodniejszy z nich, że jest THE BEST, / Żąda, by publika słuchała tylko jego „śpiewu”. / Najgorszą ze wszystkich miłości, jest MIŁOŚĆ WŁASNA (...) (Polonka 54, 2009, Miłość nie wszystko wybaczy, 22.03., blog Polonka24.redakcja.pl - NKJP 180).

(16) W powieściach Dostojewskiego Polacy nie występują nigdzie na pierwszym planie. Są postaciami akcesorialnymi, wysuwanymi w momentach najsilniejszego napięcia akcji, uderzającymi gwałtownie uczucia czytelnika, mającymi dać mu poznać całą gorycz upadku i poniżenia człowieka. W tych właśnie miejscach Polacy o chorobliwej miłości własnej zostają nagle wśród powszechnego skandalu rozpoznani jako oszuści i hultaje (...), ukrywający się pod pozorami honoru i zarozumiałości (...) (J. Stempowski, 2001, Szkice literackie. Chimera jako zwierze pociagowe: 1929-1941 - NKJP 110).

Jeśli porównamy opisane wyżej obrazowanie miłości własnej z obrazowaniem ogólnego pojęcia MIŁOŚCI zapisanego w polszczyźnie (a zbadanego także przez M. Głąbską 2014 i A. Zwierzyńską 1992), to możemy powiedzieć, że brak w konceptualizacji miłości własnej odniesień do centralnej dla prototypowej MIŁOŚCI metafory JEDNOŚCI (przy równoczesnym występowaniu wielu innych metafor wspólnych obydwu pojęciom - w różnym stopniu, m.in. odsyłających do obrazu ZWIERZCHNIKA, PRZECIWNIKA, ROŚLINY, DZIKIEGO ZWIERZĘCIA, OFIARY, CENNEGO PRZEDMIOTU, PRZEDMIOTU POZNANIA I NAUKI). 
Fakt ten sytuuje miłość własną na peryferiach miłości pojętej ogólnie (tak jak to proponowała A. Zwierzyńska). Co ciekawe jednak, w co najmniej dwóch przypadkach nawet jeśli ogólna metafora wydaje się łączyć obydwa pojęcia: miłości własnej i miłości, to specyficzne jej realizacje okazują się po części różnicujące dla tych pojęć. Tak się dzieje, po pierwsze, z umownie przez nas nazwaną metaforą SYBARYTY: choć zarówno miłość, jak i miłość własną można zaspokajać i karmić czymś, to jednak schlebianie, łechtanie, głaskanie i dogadzanie jawią się w świetle danych NKJP jako zastrzeżone wyłącznie dla miłości własnej. Po drugie, w przypadku obrazowania obydwu stanów przez odniesienie do wyobrażenia zranionej, cierpiącej ofiary różne są źródła tego cierpienia: w miłości własnej sprawca jest zewnętrzny wobec podmiotu tożsamego z obiektem, w miłości zaś - jest nim sam obiekt miłości, czyli ten, z kim podmiot czuje się związany relacją miłości.

Dodać też w tym miejscu należy, że istnienie kontekstów, w których miłość własna jest kategoryzowana jako rodzaj miłości oraz bywa oddawana za pomocą ekwiwalentnych określeń zarówno przez wyrażenie miłość własna, jak i miłość samego siebie, kochanie siebie, nie pozwala na ostre rozdzielenie tych pojęć. Można zatem na koniec zaproponować taką interpretację miłości własnej, która koncepcję A. Zwierzyńskiej rozwija i otwiera przez uwzględnienie także ujęcia Z. Zaron (odmiennego jednak metodologicznie). W interpretacji tej proponujemy pojęcie 'miłości własnej' traktować jako pojęcie złożone, wprawdzie peryferyjne wobec prototypowego rozumienia 'miłości', ale z nim powiązane i tworzące na jego obrzeżach własną (tylko częściowo dziedziczoną po nim) strukturę - z centralnym modelem negatywnie wartościowanej miłości własnej oraz mniej prototypowym, słabiej zaznaczającym się w językowym obrazowaniu, jej modelem neutralnym (w niektórych przypadkach wręcz pozytywnym). Ten drugi model charakterystyczny jest dla dyskursu refleksyjnego, przede wszystkim psychologiczno-filozoficznego (etycznego). Można zatem każdy z tych wariantów powiązać z odmiennymi punktami widzenia: negatywny - z punktem widzenia „prokuratora”, a neutralny/pozytywny - z punktem widzenia myśliciela lub terapeuty.

\section{Podsumowanie: 'miłość własna' wobec wybranych pojęć pokrewnych}

Podsumowując, możemy stwierdzić, że analiza materiałów językowych potwierdziła nasze wstępne hipotezy, dowodząc dwóch sposobów rozumienia miłości własnej w polszczyźnie współczesnej. Co istotne, każdy z nich wchodzi w różne pola pokrewnych pojęć, co oddaje w zarysie poniższa rycina. 
Ryc. 1. Milość wlasna' wobec pojęć pokrewnych
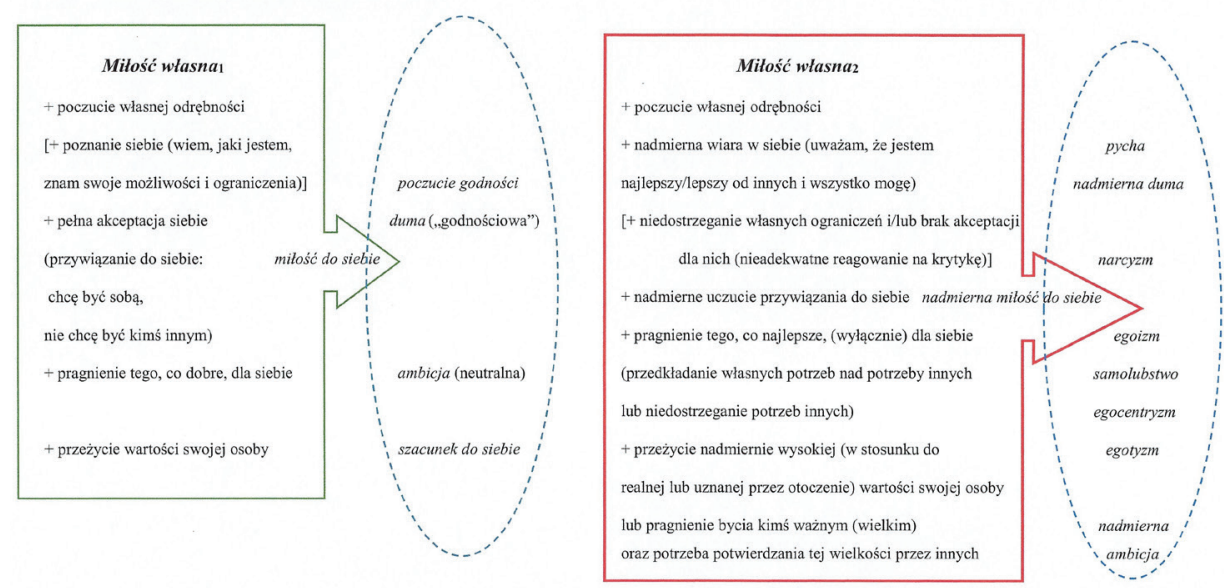

Źródło: opracowanie własne.

Wśród pojęć pokrewnych szczególnie ważne jest miejsce godności i dumy "godnościowej”, uzasadnionej (zob. Mikołajczuk 2016, 2019), sytuującej się po stronie miłości własnej (razem z neutralną ambicją oraz szacunkiem do siebie uwzględniającym szacunek do innych), a po stronie negatywnie rozumianej miłości własnej - obecność całego zestawu zaczerpniętych z psychologii nazw cech osobowości człowieka: narcyzmu, egoizmu, egotyzmu i egocentryzmu (oraz potocznego samolubstwa), a także pychy i nadmiernej dumy oraz nadmiernej ambicji.

Jak już sygnalizowałyśmy, różnice i podobieństwa między poszczególnymi pojęciami uwidaczniają się m.in. w obrazowaniu (nie ma np. ${ }^{*}$ „nieposkromionej”, * „rozjuszonej” godności, nie trzeba jej * „zaspokajać” ani * „z nią walczyć”, ale się jej „strzeże” i z trudem się ją „odzyskuje”). W przypadku ambicji jej odrębność od miłości własnej widać dodatkowo w możliwości zastosowania liczby mnogiej i częstym uzupełnianiu określeniami wskazującymi na ograniczony zakres (np. ambicje zawodowe, sportowe, edukacyjne), co zgadzałoby się z twierdzeniem Arystotelesa, iż ambicja łączy się „z tym, co średnie i małe” w przeciwieństwie do uzasadnionej dumy (zob. Arystoteles 2007, s. 159). Ponadto w 'ambicji’ na pierwszy plan wysuwa się element wolitywny (pragnienie i dążenie do sukcesów) i związana z tym perspektywa przyszłości, co nie jest tak eksponowane w 'miłości własnej'. I na koniec, widać w ambicji ciągłość semantyczną z pierwotnym znaczeniem jej łacińskiego źródłosłowu (ambitio), w którym ubieganie się o urzędy, chciwość zaszczytów, gonienie za popularnością i gorliwe staranie się o coś składały się na negatywny obraz człowieka (zob. SŁ-P, s. 32) i do dziś zdają się wpływać na możliwe negatywne konotacje tego słowa w polszczyźnie, 
chociaż określenie brak ambicji ma również zwykle ocenę ujemną, wskazując na to, że w pewnych sytuacjach ambicja jest człowiekowi potrzebna w życiu.

$\mathrm{Na}$ koniec naszych rozważań wróćmy jeszcze do problemu rozróżnienia dwóch sposobów rozumienia miłości własnej. Rozumienie neutralne (a nawet pozytywne) jest wynikiem refleksji filozoficznej i psychologicznej nad rolą stosunku człowieka do samego siebie, a więc nad postawą, którą wyraźniej opisują określenia miłość siebie, miłość do siebie, a która polega na uznaniu swojej wartości (sensu swojego istnienia), odkryciu swojej miary i dążeniu do jej wypełnienia; ta postawa otwiera człowieka na innych ludzi. Można ją nazwać miłościa własna, jak to czynią cytowani na wstępie myśliciele. Ale jest to rozumienie refleksyjne, „postulatywne”, reprezentujące punkt widzenia myśliciela lub terapeuty. System językowy utrwalił zaś silniej drugie, egoistyczne rozumienie miłości własnej, zgodnie z którym mamy tu do czynienia z wyolbrzymianiem 'ja' i zamykaniem się podmiotu na innych ludzi. Właśnie to drugie rozumienie poświadczają najczęściej zrekonstruowane na podstawie tekstów obrazowanie i utrwalona konceptualizacja. Przy próbach nadawania analizowanemu pojęciu sensu pozytywnego, które obserwujemy we współczesnej psychologii praktycznej (m.in. w Internecie), pozostaje jednak przeważnie w tle ślad pierwotnego sensu egoistycznego: skupienia na sobie, choć - jak pokazuje przykład Cz. Miłosza - widzenie swojej miary i realizowanie według niej swojego powołania (czyli „prawdziwa miłość własna”) nie skupia się na sobie. Przywołajmy jeszcze raz Miłosza:

(17) (...) Prawdziwa miłość siebie rezygnuje z poznania istotnego sensu własnego istnienia. Każe człowiekowi wypełnić jego przeznaczenie społeczne, ostatecznemu celowi użyczając cienia tajemnicy. Jest to miłość mądra, bo godzi z życiem w czasie i w przestrzeni. Jest także pokorna, bo pojmuje to życie jak obowiązek, jak rozkaz, nie usiłując przeniknąć ostatecznej jego celowości. Jest wreszcie ufna, bo niesie z sobą wiarę i nadzieję, że rozkaz mi wydany jest słuszny i celowy. Na koniec łączy z wszystkimi ludźmi podwójnym braterstwem: ziemską niedolą i ładem, który niepojętymi ogniwami spaja sprzeczności świata, krzywdy i ofiary, cierpienia i gwałty, zniszczenia i wiosenne sianie zbóż. (...) Myślę, że dopiero od momentu przyjęcia życia i własnego istnienia można mówić o konstruowaniu rzeczywistości i siebie samego. (...) Myślę poza tym, że z tej postawy wynikają pewne rygory moralne, jeśli szacunek dla drugiego człowieka i świadomość ludzkiej solidarności można określić pojęciem etycznej normy (Cz. Miłosz 1996, Legendy nowoczesności: eseje okupacyjne - NKJP 43).

Prawdziwa miłość własna to zatem odnalezienie swojego miejsca w świecie, wśród innych ludzi i przyjęcie swojego losu jako zadania. To rozumienie odbiega jednak od wysuwającego się na pierwszy plan nie tylko w dawnych, ale też w wielu tekstach współczesnych ujmowania miłości własnej jako stanu niepożądanego, bo opartego na zaburzonym obrazie siebie i innych ludzi, koncentracji na sobie 
i nadmiernym wartościowaniu siebie (lub pragnieniu bycia kimś ważnym, cennym), czego efektem są działania podmiotu ukierunkowane na własne korzyści, często kosztem innych.

\section{Bibliografia}

\section{Słowniki i źródła korpusowe}

a) Słowniki języka polskiego (w układzie chronologicznym):

SStp - Słownik staropolski, red. S. Urbańczyk. Wrocław 1953-2002;

SPXVI - Słownik polszczyzny XVI wieku, red. M.R. Mayenowa i in. Wrocław 1966-;

SJK - Słownik polszczyzny Jana Kochanowskiego, red. M. Kucała. Kraków 1994-2012;

SJPXVII - Elektroniczny słownik języka polskiego XVII i XVIII wieku, red. W. Gruszczyński, Warszawa 2004-. Pozyskano z https://sxvii.pl;

SJChP - Słownik języka Jana Chryzostoma Paska, red. H. Koneczna, W. Doroszewski, Wrocław 1965-1973;

L - Linde, S.B., Słownik języka polskiego, Warszawa 1807-1814;

SAM - Słownik języka Adama Mickiewicza, red. K. Górski, S. Hrabec, Wrocław 1962-1983;

SCN - Puzynina J., Korpysz T., Internetowy słownik języka Cypriana Norwida, Warszawa [bez daty wyd.]. Pozyskano z http://www.slownikjezykanorwida.uw.edu.pl.

SWil - Zdanowicz A. i in., Słownik języka polskiego, Wilno 1861;

SW - Słownik języka polskiego, red. J. Karłowicz, A.A. Kryński, W. Niedźwiedzki, Warszawa 1900-1927 (1952-1953 reprint);

SJPD - Słownik języka polskiego, red. W. Doroszewski, Warszawa 1958-1969;

SWBSkor - Słownik wyrazów bliskoznacznych, red. S. Skorupka, Warszawa 1968;

SFraz - S. Skorupka, Stownik frazeologiczny języka polskiego, Warszawa 1989;

SJPSz - Słownik języka polskiego, red. M. Szymczak, Warszawa 1992;

PSWPZgółk - Praktyczny słownik współczesnej polszczyzny, red. H. Zgółkowa, Poznań 1994-2005;

ISJP - Inny słownik języka polskiego, red. M. Bańko, Warszawa 2000;

WSFM-N - Müldner-Nieckowski P., Wielki słownik frazeologiczny języka polskiego, Warszawa 2005;

USJP - Uniwersalny słownik języka polskiego, red. S. Dubisz, Warszawa 2003;

NSJP - Nowy słownik języka polskiego, red. B. Dunaj, Warszawa 2005;

WSJP - Wielki słownik języka polskiego, red. P. Żmigrodzki, Kraków 2007-. 


\section{b) Inne słowniki:}

OED - Oxford English Dictionary, Oxford University Press, 1884-1933. Wersja online, wyd. 3: 2018. Pozyskano z http://www.oed.com/;

Reber, A.S. (2000). Słownik psychologii, (red.) I. Kurcz, K. Skarżyńska. Warszawa: Wydawnictwo Naukowe Scholar.

SŁ-P - Słownik łacińsko-polski, oprac. K. Kumaniecki (wg słownika H. Mengego i H. Kopii), Warszawa 1983.

\section{c) Korpusy:}

KorBa - Korpus Barokowy. Elektroniczny korpus tekstów polskich z XVII i XVIII w. (do 1772 r.), Pracownia Historii Języka Polskiego XVII i XVIII w. Instytutu Języka Polskiego PAN, kier. projektu W. Gruszczyński, koord. R. Bronikowska, Warszawa 2013-2018. Pozyskano z http://korba.edu.pl/query_corpus/;

NKJP - Bańko M. i in., Narodowy Korpus Języka Polskiego, Instytut Podstaw Informatyki PAN i in., Warszawa 2008-1012; wyszukiwarka PELCRA, korpus zrównoważony. Pozyskano z www.nkjp.pl.

\section{Literatura przedmiotu}

Appelt, K. (2005). Wiek poniemowlęcy. Jak rozpoznać potencjał dziecka. W: A.I. Brzezińska (red.), Psychologiczne portrety człowieka. Praktyczna psychologia rozwojowa (95-130), Gdańsk: Gdańskie Wydawnictwo Psychologiczne.

Апресян, В.Ю. (2011). Опыт кластерного анализа: русские и английские эмоциональные концепты, Вопросы Языкознания, 1, 19-51.

Arystoteles. (2007). Etyka Nikomachejska. Warszawa: Wydawnictwo Naukowe PWN.

Bartmiński, J. (2006). Językowe podstawy obrazu świata. Lublin: Wydawnictwo Uniwersytetu Marii Curie-Skłodowskiej.

Березович Е.Л. (2013). Как меняются оценки ценностей (на примере рус. САМОЛЮБИЕ), Etnolingwistyka, 25, 181-199.

Bierwiaczonek, B. (2002). A Cognitive Study of the Concept of LOVE in English, Katowice: Wydawnictwo Uniwersytetu Śląskiego.

Chlewiński, Z. (1999). Umyst: Dynamiczna organizacja pojęć. Analiza psychologiczna. Warszawa: Wydawnictwo Naukowe PWN.

Głąbska, M. (2014). Obraz miłości we wspótczesnym języku polskim (na podstawie analizy znaczeń leksemów kochać $i$ miłość). Warszawa: Wydział Polonistyki Uniwersytetu Warszawskiego.

Grzegorczykowa, R. (2012a). Nazwy pokory, pychy i pojęć pokrewnych. W: tejże, Świat widziany poprzez słowa. Szkice z semantyki leksykalnej (93-106), A. Mikołajczuk (red. nauk.). Warszawa: Wydawnictwa Uniwersytetu Warszawskiego. 
Grzegorczykowa, R. (2012b). Różne rozumienia wyrazu godność we współczesnej polszczyźnie. W: tejże, Świat widziany poprzez słowa. Szkice z semantyki leksykalnej (76-92), A. Mikołajczuk (red. nauk.). Warszawa: Wydawnictwa Uniwersytetu Warszawskiego.

Hatfield, E., Rapson, R.L. (2005). Miłość i procesy przywiązania. W: M. Lewis, J.M. Haviland-Jones (red.), Psychologia emocji (820-830). Gdańsk: Gdańskie Wydawnictwo Psychologiczne.

Jäkel, O. (2003). Metafory w abstrakcyjnych domenach dyskursu: kognitywno-lingwistyczna analiza metaforycznych modeli aktywności umysłowej, gospodarki i nauki. Kraków: Universitas.

Jakubowicz, M. (2000). Dwa oblicza miłości. Porównanie językowych obrazów miłości tkwiących w etymologii i frazeologii. W: I. Nowakowska-Kempna, A. Dąbrowska, J. Anusiewicz (red.), Uczucia w języku i w tekście (233-243), seria "Język a Kultura", t. 14. Wrocław: Wydawnictwo Uniwersytetu Wrocławskiego.

Kövecses, Z. (1986). Metaphors of Anger, Pride and Love. Amsterdam-Filadelfia: John Benjamins Publishing.

Kövecses, Z. (1998). Are there any emotion-specific metaphors? W: A. Athanasiadou, E. Tabakowska (red.), Speaking of Emotions. Conceptualisation and Expression (127-151). Berlin-New York: Mouton de Gruyter.

Kövecses, Z. (2011). Miłość to podróż: studium przypadku różnic kulturowych w wyrażeniach metaforycznych. W: tegoż, Język, umyst, kultura. Praktyczne wprowadzenie (255-262). Kraków: Universitas.

Lakoff, G., Johnson, M. (1988). Metafory w naszym życiu, tłum. T. Krzeszowski. Warszawa: Państwowy Instytut Wydawniczy.

Lewis, M. (2005a). Emocje samoświadomościowe: zażenowanie, duma, wstyd, poczucie winy. W: M. Lewis, J.M. Haviland-Jones (red.), Psychologia emocji (780-797). Gdańsk: Gdańskie Wydawnictwo Psychologiczne.

Lewis, M. (2005b). Wyłanianie się ludzkich emocji. W: M. Lewis, J.M. Haviland-Jones (red.), Psychologia emocji (342-360). Gdańsk: Gdańskie Wydawnictwo Psychologiczne.

Marcinów, M. (2017). Miłość własna skłania do boleści (Minasowicz, 1771). W: tejże, Historia polskiego szaleństwa, t. I: Słońce wśród czarnego nieba. Studium melancholii (134-135). Gdańsk: Fundacja Terytoria Książki.

Mikołajczuk, A. (2016). Czy duma to przeżycie odświętne? Z badań nad konceptualizacją dumy (ang. pride) w polszczyźnie. Je duma (hrdost / pycha) prožitkem svátečním? Z výzkumu konceptualizace hrdosti / pychy (angl. pride) v polštině (Shrnutí). W: L. Saicová Rímalová, I. Vaňková (red.), Lidský život a každodennost v jazyce (105-119). Praha: Univerzita Karlova, Filozofická fakulta.

Mikołajczuk, A. (2019). Complex concept of DUMA ('pride') in Polish - from a lexicographic approach to discourse analysis. W: M. Grygiel, R. Kiełtyka (red.), Cognitive Linguistics in the Year 2017 (21-34). Berlin: Peter Lang. 
Smykowski, B. (2005). Wiek przedszkolny. Jak rozpoznać potencjał dziecka W: A.I. Brzezińska (red.), Psychologiczne portrety człowieka. Praktyczna psychologia rozwojowa (165-205). Gdańsk: Gdańskie Wydawnictwo Psychologiczne.

Tylikowska, A. (2018). „JA”, czyli kto? Człowiek w egolandii. Krótka historia JA i pojęć pokrewnych, Ja My Oni. Poradnik Psychologiczny, Polityka, 30: Do czego nam EGO. Pozyskano z www.polityka.pl/jamyoni/1747974,1,ja-czyli-kto.read.

Wierzbicka, A. (1971). Kocha - lubi-szanuje. Medytacje semantyczne. Warszawa: Wiedza Powszechna.

Wojciszke, B. (2005). Psychologia miłości. Intymność. Namiętność. Zaangażowanie. Gdańsk: Gdańskie Wydawnictwo Psychologiczne.

Zaron, Z. (1985). Wybrane pojęcia etyczne w analizie semantycznej (kochaj bliźniego swego). Wrocław: Zakład Narodowy im. Ossolińskich.

Zwierzyńska, A. (1992). Wyidealizowane modele kognitywne pojęcia „miłość” i „love” przedstawionego w przysłowiach polskich i angielskich. W: I. Nowakowska-Kempna (red.), Podstawy metodologiczne semantyki współczesnej (91-112), seria „Język a kultura", t. 8. Wrocław: Wiedza o Kulturze.

\section{Streszczenie}

W artykule przedstawiamy dzieje wyrażenia miłość własna (stabilizującego się w języku polskim między XVII a końcem XVIII w.) i jego współczesne rozumienie, w tym w psychologii. W wyniku analizy semantycznej (z wykorzystaniem językowych korpusów XVII-XVIII i XX-XXI w.) wydzielamy dwa sposoby rozumienia tego wyrażenia: 1) 'miłość własną, - neutralny stan psychiczny, który obejmuje: 'poczucie swojej odrębności, akceptację siebie, pragnienie dobra dla siebie i poczucie własnej wartości'; 2) 'miłość własną, - oceniany negatywnie stan psychiczny, który obejmuje: 'wyolbrzymione poczucie własnej wartości, pragnienie dobra wyłącznie dla siebie, pragnienie uznania ze strony innych' Na koniec rekonstruujemy metaforyczne obrazowanie miłości własnej utrwalone we współczesnej polszczyźnie. 